University of Minnesota Morris Digital Well

University of Minnesota Morris Digital Well

History Publications

Faculty and Staff Scholarship

Winter 2020

\title{
Playing on the Map: An Educational Game from the Age of Revolutions
}

\author{
Emily C. Bruce \\ University of Minnesota - Morris, bruce088@umn.edu \\ Elise Klarenbeek \\ University of Minnesota - Morris, klare008@morris.umn.edu
}

Follow this and additional works at: https://digitalcommons.morris.umn.edu/history

Part of the European History Commons

\section{Recommended Citation}

Bruce, Emily and Elise Klarenbeek. "Playing on the Map: An Educational Game from the Age of Revolutions." The Journal of the History of Childhood and Youth 13, no. 1 (2020): 9-17.

This Article is brought to you for free and open access by the Faculty and Staff Scholarship at University of Minnesota Morris Digital Well. It has been accepted for inclusion in History Publications by an authorized administrator of University of Minnesota Morris Digital Well. For more information, please contact skulann@morris.umn.edu. 


\section{Playing on the Map: An Educational Game from the Age of Revolutions ${ }^{1}$}

The use of games as an instructional tool might seem characteristic of pedagogy today. Yet the years around 1800 actually offer important clues to understanding the emergence of play as part of an idealized education in the modern world. As a protoexample of today's "edutainment," our object lesson is at once remarkable and ordinary. This German geography board game, "The Journey from Prague to Vienna" (“Die Reise von Prag nach Wien"), was produced sometime in the late eighteenth or early nineteenth century. Its spatial orientation, colorful narration, and, it turns out, gameplay itself reveal much about how middle-class German-speaking children were situated socially and politically in the world.

Children playing "The Journey from Prague to Vienna" likely drew on their experience of other games. ${ }^{2}$ Board games have existed in some fashion for thousands of years around the world, but during the late eighteenth century in Europe they began to be marketed for children's use in particular. ${ }^{3}$ At the same time, geography emerged as the quintessential topic for board games. In 1752, John Jefferys published "A Journey through Europe, or the Play of Geography" (1752), which, like “The Journey from Prague to Vienna," took players on a tour of distinctive features such as might be noted in the long-standing genre of travel narratives. ${ }^{4}$ But the form of a game may have more directly elicited players' desires, as Koca Mehmet Kentel argues: “Through playing those games, travelling to distant parts of the world, learning to look at 'things' of the world as legitimate objects to acquire...children were made to orient themselves within 
an imperial horizon, to take it as a mundane experience." 5 This fantasy of consumption fed the ideology of domesticity as much as it did imperial knowledge production.

Since board game scholarship has often focused on England, our early Germanlanguage example is especially intriguing. ${ }^{6}$ The very different political contexts of Britain and the shifting borders of Central Europe before German unification at this time are also key. But the most important difference between “The Journey from Prague to Vienna" and the English games by Jefferys, John Wallis, and others is that the latter group provided key geographic facts as an integral part of the game. ${ }^{7}$ By contrast, German children playing "The Journey from Prague to Vienna" were expected to supply their own geography answers based on their education.

It is not a coincidence that this game dealt with geography. ${ }^{8}$ The standard European approach to geographical education in the eighteenth century was purely descriptive, and students learned through rigid, memorization-driven instruction. However, the early nineteenth century saw developments in pedagogic philosophy and shifts in geographic epistemology that, by the middle of the century, began to produce a modern form of geographic education. Factors which contributed to changes in geographical thought include the map-scrambling Napoleonic wars, the beginnings of colonial knowledge production, and intensifying travel activities in a world of improved roads, ships, and postal networks. These led to new, distinct features of children's geographic education: growing concern for child readers' amusement, an association of learning about the world with the family and the home, the orientation of children in space as explorers and armchair travelers, an increased emphasis on map- 
reading and the use of atlases in schools, and the influence of nationalism and colonial ambitions. The new geographic pedagogy developing in the years around 1800 was marked by a move towards method and away from topical classification, the specialization of learning based on students' age, and, most importantly, an emphasis on individual experience and observation..$^{9}$ The format of a board game thus afforded Enlightenment pedagogues an ideal, amusing instrument for encouraging children to problem-solve, read maps, and engage with the world.

The first copy of "The Journey from Prague to Vienna" that we encountered (the only extant, according to WorldCat) is held in the Cotsen Children's Library at Princeton University. At some point it became part of a private collection on "The History of Transportation in France and Related Subjects" assembled by amateur historian William P. Davisson and was sold at auction in 1999.10 The Christie's staff listed the artifact's date as circa 1780, but we have reason to believe its origin is a little later-more on that in a moment.

The board is 16.5 by 14 inches of laid paper on a cardboard mount, which is likely more recent than the game itself. While most surviving board games from the eighteenth century were mounted on linen maps, such games were also available as unmounted sheets that were much less likely to survive. The blue slipcase for the Cotsen copy of this game is also likely a later addition, as it has no title label but does include the initials R.P.W. (for some owner preceding Davisson). The only instructions in the Cotsen version are on a separate sheet of paper, in French. Even as early as 1800, Germany was a major center for the production of toys and games of all kinds intended 
for audiences across Europe, so instructions and rules were usually printed multilingually in French, German, English, and sometimes Italian. ${ }^{11}$ According to Cotsen Curator Andrea Immel, the German-language rules and publisher's imprint may have been trimmed away when the game was mounted.

We later made an unexpected discovery: a copy of the game instructions (in German, but otherwise identical to the French rules in the Cotsen version) and a paper fold-out of the game were included at the back of a youth periodical published in Nuremberg in 1805.12 The publication's author, Gotthold Emmanuel Friedrich Seidel (1774-1838), was a theologian and occasional writer of works for young readers, including this Youth Almanac for the Year 1805.13 The contents were typical for Enlightenment youth periodicals: odds and ends of poetry, dialogue, didactic essays, engravings, and stories. ${ }^{14}$ Although published in Bavaria, the book was reviewed in Berlin, suggesting its transnational scope. ${ }^{15}$ So, which came first, the standalone copy in the Cotsen Library or the version in this youth periodical? The first possible scenario is that Seidel created the game for his periodical and a buyer cut the game for personal use; while this seems unlikely because of printed French-language rules in the Cotsen copy, Seidel's biography does note his skill in drawing and interest in travel. A second scenario is that Seidel encountered the game now held at the Cotsen and copied it for his book; this kind of "borrowing" was rife in early nineteenth-century print culture. Finally, the third scenario is that both the 1805 youth almanac version and the Cotsen game were copied from some other original source. At this point, we cannot state with 
certainty whether the Cotsen copy is the original game or was derived from an earlier version.

"The Journey From Prague to Vienna" is a "race game," in which four young players attempt to be the first to arrive at the final city. During the journey, each player holds a job: either doctor, cartwright, customs inspector, or postilion. The instructions suggest that the player who is most familiar with geography should be appointed Director, with a note indicating turns as Director may be shared if several players want the role. Players advance around a single winding path by rolling dice to move cones of different-colored wax. ${ }^{16}$ Before the game can begin, players must equally contribute to a stake totaling fifty marks, which grows throughout the game as prompted by the instructions. Upon arrival at a city, the player must answer a geography question about it, or lose marks for a wrong answer. As penalty for accepting a wrong answer, the Director must pay. At different points throughout the game, players arrive at locations that harbor dangers or cause misfortunes, as depicted by several miniature drawings around the board. For example, a player might be arrested and locked in a tower, ransacked by robbers in the Spessart forest, or even drown in Lake Constance. However, perhaps the most dramatic moments occur when a player loses all marks and must return to Prague and restart the journey. The instructions suggest that this player invent the circumstances that have resulted in beggary, and that the other players be forced to return half the begging player's wealth as a reward for a good story. To win the game, players must arrive at Vienna on a dice roll that takes them directly to the city, and successfully answer one last geography question. 
In our efforts to discover more about the game, we concluded that the next obvious step would be to play it. After gathering some willing colleagues, we made slight modifications to the original rules. A starting amount of money per player is not specified by the instructions, so each player in our game began with thirty-five marks, which we represented with Monopoly money, and each player contributed fifteen marks to the stake. Similarly, the instructions do not specify which player should start or the order of play. Even during the game set-up, we realized that despite seeming elaborate on the page, the rules of the game are not as complex as the mechanisms of a twenty-first-century game. Since most twenty-first-century Americans do not know a great deal about German geography, we replaced every city on the board with a somewhat parallel North American city. Although this is an educational game in which the outcome depends on players demonstrating their geographic knowledge, chance plays a significant role and players have no ability to create strategies. We quickly understood the importance of chance by discovering that it is an advantage to land on numbered spots rather than cities, as players do not have to answer a geography question there and risk losing money. Further, while young players around 1800 were encouraged to identify German cities through commerce, naming distinctive manufactured goods or agricultural products that the city would have been known to produce, we discovered the equivalence for twenty-first-century players was to name sports franchises. We also found that the game seems to be fairly replayable, since there were plenty of entertaining mishaps left on the board that no one landed on before someone won. 
As was typical of an era on the brink of radical educational transformations, the pedagogical model of this game presents several contradictions. On the one hand, it seems to encourage the idea that education should be amusing by providing geography instruction through a game versus the dry textbooks of the past. On the other hand, the requirement to recite answers based on a shared, limited set of knowledge essentially follows an older, catechetical approach to learning. We realized during our experimental play-through that even one short iteration of the game perforce involves landing on the same city multiple times. The rules do not specify whether players needed to come up with new answers on repeat visits or could just learn and repeat one fact again and again. We opted for the former in our playthrough, and as a result one player was obligated to come up with a different fact about Grand Rapids, Minnesota on each of the four times she landed on it-no small feat. This added difficulty demonstrates how the game captures a moment of transition in education - while at times the game is amusing, it is still designed around a bounded body of knowledge rather than creative interpretation and problem-solving.

Suffused throughout the misadventures imagined on the game board and the mechanism of gameplay is reinforcement of class position. The management of money (what we might call financial literacy) was a recurring theme. For example, if a player landed on Augsburg and won five marks in clocks, and shortly after landed on number seventy-six where the customs inspector resides, they would have to pay six marks. By doing so, players practiced managing money in a commercially-oriented bureaucracy. The fact that rivers were the only natural features marked on the board also suggests an 
orientation toward trade. That said, players were not actually able to demonstrate their financial acumen by strategizing and husbanding their funds (as in more modern games like Monopoly). Nor did the non-elite occupations taken on by each player reflect the reality of social position for this game's likely audience; young bourgeois players did not have to know anything about the reality of, say, a postilion's labor in order to succeed in that role. Instead, the function of money in the game was descriptive, reminding players of the importance of cash, debts, and other workings of capitalism. The game's content underscores the well-observed dynamic that for the educated bourgeoisie at this moment, identity was more about class than about nation or empire. ${ }^{17}$ The spaces explored by the game were highly localized rather than associated with national cultural identities.

The game was created in the midst of nationalist stirrings across Central Europe. In 1797, Goethe and Schiller published a series of sharply political verses called Xenien, in which they wrote "Germany? But where does it lie? I do not know how to find that country." 18 Liberal nationalists, inspired both by the political philosophy of the Enlightenment and the experience of Napoleonic invasion, were dreaming of a unified German state. The German Question was whether this imagined nation-state would center on Prussia (the "Lesser Germany" solution) or would include and be led by Austria (the "Greater Germany" solution). ${ }^{19}$

In some ways, "The Journey from Prague to Vienna" exhibits indifference toward the question of nationalism, starting with the inclusion of Central European cities across political regimes without emphasizing borders between, for example, 
Austria and Prussia. A player who truly stumbles might be sent back to a spot on the map ("Number 0 ") preceding the official start of the game in Prague. The destination is Pressburg - the earlier, Germanic name for Bratislava. Although today the capital of Slovakia, at the time of this game the city was very much a border town within the German-speaking view of Central Europe (on the border of Austria and Hungary) and was on the decline by the time this game was created. ${ }^{20}$ Though explicitly marked as on the margins by the game design, Pressburg/Bratislava was still included in a capacious sense of the German map. Furthermore, the events and imagery of the game include not a single reference to religion, nor signals of confession. Neither Prussian Protestantism nor Austrian Catholicism dominated the landscape.

Yet this version of national indifference in fact tilts the game toward one solution. The German Question was answered in "The Journey from Prague to Vienna" with a culturally imagined German nation at least including if not ruled by Austria. The game rules begin, for example, with the phrase "You see before you a map of Germany." German language and German cultural identity was more salient than political borders in this game, as can also be seen in many school atlases of the time..$^{21}$ We found a striking if not surprising absence of Italian-speaking places in Tyrol, Italianor French-speaking in Switzerland or Alsace, Polish-speaking regions in what was then Prussia, and Czech-, Hungarian-, or Slovakian-speaking areas of Central Europe. Sizable cities that are geographically close to places marked on the game's map did not appear on the board unless they were predominantly German-speaking at the time of the game. ${ }^{22}$ With this emphasis on linguistic unity, the game depicts a German-speaking 
world oriented toward Austria. And although there is clear evidence that Austrian children were not the sole intended audience for the game, both the starting point and the destination of this race lie within the Austrian Empire - placing it at the center of an imagined German nation.

There are always political consequences for the socialization of children into a particular geographic viewpoint. In the Age of Napoleon, those stakes were raised. Within a world rife with political instability and emerging nationalist mobilizations, "The Journey from Prague to Vienna" taught bourgeois youth that they shared in an imagined German cultural identity. The game also reminded young players that their class power as adults would be shored up through commercial enterprise. An intriguing future line of inquiry might build on historical studies of individual board games by systematically comparing the moral lessons they sought to convey to young people. What is clear already is that both socialization and play traveled with children as they raced around the map in the Age of Revolutions. 
${ }^{1}$ The initial research for this essay was funded by a grant from the Friends of the Princeton University Library; our collaboration was supported by the Morris Academic Partnership Program through the University of Minnesota Morris Dean's Office. We would like to thank our intrepid game-testers (Joseph Broding, LeAnn Dean, Naomi Skulan, and Angela Stangl), as well as Joseph Beaver, Andrea Immel, and Elizabeth Lefebvre for feedback on a draft.

${ }^{2}$ Despite the popularity of eighteenth-century board games, they have typically been treated as suitable for antiquarian interest rather than serious historical scholarship. Koca Mehmet Kentel, “Empire on a Board: Navigating the British Empire through Geographical Board Games in the Nineteenth Century," The Portolan: Journal of the Washington Map Society no. 102 (Fall 2018): 28.

${ }^{3}$ See Caroline G. Goodfellow, "The Development of the English Board Game, 1770-1850," Board Game Studies no. 1 (1998): 70-80; David Sidney Parlett, The Oxford History of Board Games (Oxford: Oxford University Press, 1999); Jill Shefrin, The Dartons: Publishers of Educational Aids, Pastimes E Juvenile Ephemera, 1787-1876 (Los Angeles: Cotsen Occasional Press, 2009).

${ }^{4}$ Francis Reginald Beaman Whitehouse, Table Games of Georgian and Victorian Days (London: Priory House, 1951), 6. On eighteenth- and nineteenth-century British board games, see also Jane Dove, "Geographical Board Game: Promoting Tourism and Travel in Georgian England and Wales," Journal of Tourism History 8, no. 1 (2016): 1-18; Kentel, “Empire on a Board": 27-42.

${ }^{5}$ Kentel, “Empire on a Board": 34.

${ }^{6}$ On the history of German games (mostly twentieth-century), see the German Game Archive in Nuremberg (Deutsches Spielarchiv Nürnberg), whose website proclaims that "German is the country of game players," accessed December 19, 2013, http://deutsches-spiele-archiv.de.

${ }^{7}$ Dove, “Geographical Board Game”: 8.

${ }^{8}$ Kentel, “Empire on a Board": 28. 
${ }^{9}$ On some aspects of the transforming geographic education of this era, see Chenxi Tang, The Geographic Imagination of Modernity: Geography, Literature, and Philosophy in German Romanticism (Stanford, CA: Stanford University Press, 2008).

${ }^{10}$ David H. Stam, What Happened to Me: My Life with Books, Research Libraries, and Performing Arts (Bloomington, IN: AuthorHouse, 2014), 102-104.

11 Bryan Ganaway, Toys, Consumption, and Middle-class Childhood in Imperial Germany, 1871-1918 (Bern: Peter Lang, 2009); David Hamlin, Work and Play: The Production and Consumption of Toys in Germany, 1870 1914 (Ann Arbor: University of Michigan Press, 2007).

${ }^{12}$ Gotthold Emmanuel Friedrich Seidel, Jugendkalender für das Jahr 1805 (Nuremberg: J. E. Seidelschen, 1805).

${ }^{13}$ Ernst Mummenhoff, "Seidel, Gotthold Emanuel Friedrich" in Allgemeine Deutsche Biographie 33 (1891), 619-20, https:/ / www.deutsche-biographie.de/pnd117455148.html.

${ }^{14}$ For more on the rise of Enlightenment youth periodicals, see Emily C. Bruce, "Reading German Girlhood: Louise Tilly and the Agency of Girls in European History," Social Science History 38 (2014): 97103.

${ }^{15}$ Seidel's almanac was reviewed or advertised in several venues, including the Intelligenzbaltt der Zeitung für die elegante Welt 60, December 11, 1804.

${ }^{16}$ Although the direct route from Prague to Vienna is 200 miles long, the game path covers some 4500 miles of territory.

17 On the history of cultural nationalism and regionalism in Central Europe, see Celia Applegate, A Nation of Provincials: The German Idea of Heimat (Berkeley: University of California Press, 1990); Alon Confino, The Nation as a Local Metaphor: Wurttemberg, Imperial Germany, and National Memory, 1871-1918 (Chapel Hill: University of North Carolina Press, 1997); Tara Zahra, Kidnapped Souls: National Indifference and the Battle for Children in the Bohemian Lands, 1900-1948 (Ithaca: Cornell University Press, 2008).

18 Xenien Chapter 1, Number 95 (1796). 
19 David Blackbourn, History of Germany 1780-1918: The Long Nineteenth Century, 2nd ed. (Oxford: Blackwell, 2003), xvi-xvii.

${ }^{20}$ German-speakers were the dominant group in Pressburg around 1800, but the city was also home to Hungarian- and Slovak-speakrers, including a significant Jewish population. On the changing name, see Anton Spiesz, Illustrated Slovak History: A Struggle for Sovereignty in Central Europe, trans. Joseph J. Palus, Jr., et al. (Wauconda, IL: Bolchazy-Carducci Publishers, 2006), 326n3.

${ }^{21}$ For example, Johann Heckel, Atlas für die Jugend: und alle Liebhaber der Geographie (Augspurg: Conrad Heinrich Stage, 1791); Adam Christian Gaspari, Lehrbuch der Erdbeschreibung: zur Erläuterung des neuen methodischen Schulatlasses (Weimar: Verlag des Geographischen Instituts, 1806).

22 Specifically, we compared the game against two contemporaneous atlases: C. G. Reichard, Atlas des ganzen Erdkreises (Weimar: Landes Industrie Comptoir, 1803); William Guthrie, Atlas to Guthrie's Geographical Grammar (London: Walker, Wilkie, and Robinson, 1805). 